\title{
Strategi Adaptasi Nelayan Lanjut Usia Dan Hubungannya Dengan Ketahanan Sosial. Studi Kasus Di Nagari Air Bangis, Kecamatan Sungai Beremas, Kabupaten Pasaman Barat ${ }^{1}$
}

\author{
Ermayant $^{2}$
}

\begin{abstract}
Human existence as living beings will keep trying to make ends meet, despite his advanced age. Reality that they are not engaged by the employer group requiring them to implement various strategies in order to fulfill the necessities of life for yourself and family is maintained. This is possible as an option strategy adaptation in the elderly fishermen anticipate the changes that occur in the life of the fishing community.
\end{abstract}

This study aims to describe the fishing community adaptation strategies in the face of the elderly. Future elderly fishing communities are determined based on the sociocultural level of productivity that is generated, are still actively searching for fish on the high seas or just along the coast. Productive age limit directly affects the revenue lost fishermen. This fact led to the emergence of a variety of problems experienced by elderly fishermen, both from the economic, psychological, social and cultural.

The families of elderly fisherman as the unit of analysis in this study have similar characteristics with elderly fishermen in general. A qualitative approach is emphasized in the process of collecting and analyzing the data. For that, although using the analysis in several families of elderly fishermen, but the problems are representative of elderly fisherman can span the 'hierarchy.

The results showed that the main strategy applied elderly fisherman is still maintaining fishermen job, considering the social and cultural environment sulir fishing communities offer alternatives for another job. In addition, elderly family strategy in fulfilling its economy is the income earned, usually in debt to the tauke or indebted to anyone who would give him a loan debt. Aside from the elderly fisherman fishermen borrow another boat and look for alternative livelihoods outside between fishermen, such as gathering firewood to be sold to people in need. In addition, the results showed that elderly fisherman efforts to realize social security is to improve safety in these villages with mutual respect, tolerance and collaboration, because the villagers' Air Bangis already feel safe. In Nagari Air Bangis rarely finds conflicts between fishermen here, even if there was only a small problem, which can be directly solved maslaah. Usually the elderly fisherman to keep track of security among citizens just always maintain good relations between people, mutual help for anyone who needs and mutually saluted each other. Not distinguish economic status or the status of their fishermen. The main problem in this village is still the economic problems of society, because there are many people here who are in the poverty level.

Keywords: Elderly Fishermen, Adaptation Strategy, Choice, Sosial Security

\footnotetext{
${ }^{1}$ Artikel ini merupakan hasil penelitian yang didanai oleh Penelitian Mandiri DIPA Universitas Andalas tahun anggaran 2011

${ }^{2}$ Penulis adalah dosen tetap Jurusan Antropologi FISIP Universitas Andalas
} 


\subsection{Latar Belakang}

ehidupan suatu masyarakat
senantiasa mengalami berbagai
perkembangan ditinjau dari berbagai dimensinya, baik aspek sosial, budaya maupun ekonomi. Perkembangan ini berdasarkan oleh adanya interaksi antar individu yang membentuk masyarakat dan mewarnai aktivitas kehidupan manusia secara keseluruhan. Masyarakat sebagai senyawa dari jiwa individu-individu yang terintegrasi tanpa terlihat unsur-unsur pembentuknya. Persenyawaan ini pada hakikatnya bukan terletak pada unsur fisiknya, akan tetapi abstraksi dari pikiran, kehendak serta hasrat yang dimiliki oleh masyarakat yang bersangkutan (Mutahari, 1986:22).

Setiap individu dalam masyarakat memiliki ketergantungan dengan individu lainnya dalam usaha untuk pemenuhan kebutuhan hidup. Dalam kaitan yang sama, individu juga memiliki naluri untuk hidup bersama dengan individu lain, karena memang setiap individu memiliki keterbatasan dan tidak diperlengkapi oleh organ yang cukup untuk dapat hidup sendiri. Untuk menutupi kekurangan tersebut, setiap individu memanfaatkan akal secara maksimal.

Sikap saling ketergantungan dalam konteks pemenuhan kebutuhan hidup akan semakin terasa ketika individu tengah memasuki masa lanjut usia akibat dari pertambahan usia; suatu proses yang tidak dapat dihindari oleh seorang individu. Banyak kemampuan berkurang pada saat orang menjadi tua, padahal persoalan orang lanjut usia bukan semata-mata menjadi persoalan individu yang bersangkutan, melainkan juga melibatkan unsur keluarga serta masyarakat secara keseluruhan. Apalagi pada dekade terakhir, jumlah orang lanjut usia semakin bertamah secara signifikan dan mempengaruhi komposisi demografis secara keseluruhan.

Indonesia adalah salah satu negara yang termasuk ke dalam zaman penduduk berstruktur lanjut usia (aging struktured population) dengan jumlah persentase penduduk lansia sekitar $7,18 \%$. Peningkatan jumlah penduduk lansia ini antara lain disebabkan 1) tingkat sosial ekonomi masyarakat yang meningkat, 2) kemajuan di bidang pelayanan kesehatan, dan 3) tingkat pengetahuan masyarakat yang meningkat. $^{3}$

Semakin baiknya tingkat sosial ekonomi masyarakat, kemajuan pelayanan kesehatan masyarakat dan sadar hidup sehat secara otomatis telah meningkatkan angka harapan hidup manusia, yang berimplikasi kepada jumlah penduduk usia lanjut yang semakin meningkat pula. Dari hasil perbandingan jumlah penduduk berusia tua (lansia) sejak 1971, tingkat angka harapan hidup tadi berkisar antara 4,5 persen atau 5,3 juta jiwa. Namun dalam catatan pada tahun 2000 menunjukkan, jumlah tersebut meningkat hampir tiga kali lipat menjadi 14,4 juta, dan pada tahun 2020 diproyeksikan jumlah penduduk lansia di Indonesia diperkirakan terus meningkatkan menjadi 28,8 juta atau berkisar sampai 11,34 persen. ${ }^{4}$ Nugroho

(1995:13-14) menguraikan beberapa pendapat mengenai batasan umur bagi lanjut usia antara lain;

(1) Menurut Organisasi Kesehatan Dunia (WHO), lanjut usia meliputi usia pertengahan (middle age), yaitu kelompok usia 45 sampai 59 tahun; usia lanjut (elderly), usia antara 60 sampai 70 tahun; usia lanjut tua (old), usia antara 71 sampai 90 tahun dan usia sangat tua (very old), usia di atas 90 tahun.

(2) Menurut Undang-undang Republik Indonesia No. 13 tahun 1998 tentang kesejahteraan lanjut usia, meliputi; kelompok early-old, yaitu usia antara 56-64 tahun; kelompok young-old, yaitu usia natara 64-74 tahun, dan kelompok old-old, yaitu usia 75 tahun ke atas.

Http://www.menkokesra.go.id, Lansia Masa Kini dan Sekarang (17 Januari 2009, 11:07).

Http://www.padangekspres.co.id/content/v iew/23022/106/, Angka Harapan Hidup Tinggi, Penyandang Cacat dan Lansia Diberi Perlindungan (Sabtu, 15 November 2008). 
Menurut Masdani, lanjut usia merupakan kelanjutan dari usia dewasa yang dibagi dalam empat bagian, yaitu; fase inventus, yaitu usia antara 25 sampai 40 tahun; fase verilitas, yaitu usia antara 40 sampai 50 tahun; fase proesenium, yaitu usia antara 55 sampai 65 tahun dan fase senium, yaitu usia antara 65 tahun sampai tutup usia. Sedangkan menurut Setyonegoro, pengelompokkan lanjut usia meliputi; usia dewasa muda (elderly adulthood) yaitu 18/20-25 tahun; usia dewasa penuh (middle years) atau maturitas yaitu 25-60/65 tahun dan lanjut usia (geriatric age) lebih dari 65-70 tahun. Terbagi untuk umur 70-75 tahun (young old), 75-80 tahun (old) dan lebih dari 80 tahun (very old) (Budiaman, 2002;8). Kalau dilihat dari kategorisasi umur lanjut usia dari beberapa ahli tersebut di atas, dapat disimpulkan bahwa yang disebut lanjut usia adalah orang yang telah berumur 60 tahun ke atas. Berdasarkan kategori tersebut, maka jumlah lanjut usia akan semakin bertambah seiring peningkatan derajat kesehatan masyarakat.

Penduduk lanjut usia merupakan kelompok penduduk yang mempunyai resiko tinggi untuk sering sakit dan menderita sakit kronis, serta mengalami ketidakmampuan. Terdapat ada tiga pola penyakit utama lansia, yaitu a) gangguan degeneratif seperti gangguan peredaran darah karena pengerasan pembuluh darah b) gangguan metabolik misalnya radang sendi, anemia dan hipthyroid dan c) gangguan kesehatan lain misalnya infeksi, trauma dan kurang nafsu makan (Menko Kesra, 1996).

Bagi sebagian besar masyarakat nelayan, masa lanjut usia berpengaruh secara nyata terhadap tingkat pemenuhan kebutuhan hidup. Masa-masa ini dianggap sebagai masa yang sulit dalam perekonomian; sementara dalam konteks sosial budaya berkurangnya peran individu dalam sektor ekonomi menyebabkan perubahan tingkat apresiasi masyarakat terhadap individu yang bersangkutan. Masa-masa lanjut usia pada umumnya diharapkan oleh setiap individu sebagai masa untuk menikmati sisa hidup setelah bekerja keras selama masa usia produktif dengan tercukupi kebutuhan biologis, ekonomi dan penghargaan dari masyarakat sebagai lanjut usia yang dianggap berhasil. Dalam kenyataannya tidak semua lanjut usia dapat mencapai kondisi sesuai dengan yang diharapkan.

Dalam kaitan ini, pemilik perahu (induk semang/juragan) beranggapan bahwa pekerjaan mencari ikan di laut memerlukan keterampilan dan kekuatan fisik yang prima. Induk semang/juragan tidak mau mengambil banyak resiko, seperti resiko kesehatan dan biaya produksi tinggi, dengan mempekerjakan nelayan yang sudah dipandang lanjut usia. Fenomena ini disebabkan oleh semakin tingginya target produksi para nelayan di masa krisis ekonomi sekarang ini. Hal ini kemudian terjadi berkenaan dengan kondisi bergesernya peran lanjut usia dari sektor industri utama, digantikan oleh tenaga-tenaga muda yang dianggap lebih potensial. Bahkan ada induk semang/juragan yang tidak lagi mempekerjakan tenaga awak perahu apabila suah melewati usia 45 tahun. Akibatnya, nelayan lanjut usia banyak yang beralih ke pekerjaan lain, sebagian besar masih berhubungan dengan kenelayanan yang tidak mengandalkan kekuatan fisik atau sama sekali tidak berhubungan dengan kenelayanan.

\subsection{Perumusan Masalah}

Dermasalahan hidup yang dihadapi keluarga nelayan lanjut usia pada umumnya berkisar pada kekurangan sumber ekonomi dalam memenuhi kebutuhan hidup sehari-hari, transisi psikososial akibat berubahnya kedudukan dan pola hubungan sosial, sulitnya mendapatkan modal untuk mengembangkan usaha serta kesehatan yang mulai menurun. Kondisi fisik dan lingkungan sosial budaya yang telah berubah membuat nelayan lanjut usia harus menerima kenyataan yang ada. Akan tetapi, hal ini tidak harus menjadikan nelayan lanjut usia sebagai beban keluarga dan masyarakat.

Di propinsi Sumatera Barat, khususnya masyarakat nelayan pada daerah pesisir pantai Kabupaten Pasaman Barat memperlihatkan kondisi faktual masyarakat nelayan lanjut usia 
yang masih produktif dalam menjalankan aktivitas kenelayanan. Menurut data BPS Pasaman Barat, khususnya di Nagari Air Bangis, Kecamatan Sungai Beremas (2008), berkisar 12\% (2402 orang). Data diatas memperlihatkan bahwa masyarakat nelayan lanjut usia masih termasuk ke dalam jumlah yang besar dan memiliki peranan yang signifikan dalam peningkatan ekonomi masyarakat nelayan. Kategori masyarakat nelayan lanjut usia di kecamatan ini adalah berada pada usia 55 tahun sampai $75 \mathrm{ke}$ atas.

Hasil observasi pendahuluan, bahwa lokasi penelitian yang telah ditetapkan yaitu Nagari Air Bangis, Kecamatan Sungai Beremas, Kabupaten Pasaman Barat memperlihatkan bahwa masyarakat nelayan lanjut usia memiliki strategi-strategi pilihan dalam meningkatkan ekonomi rumah tangga, yang akhirnya mereka tidak terbebani oleh faktor usia dan kenyataan hidup yang tidak memberikan peluang bagi mereka untuk tetap melakukan aktivitas kenelayanan.

Berdasarkan latar belakang di atas, maka perumusan permasalahan adalah sebagai berikut: apakah kondisi riil yang dihadapi oleh nelayan lanjut usia dan apakah pilihan strategi adaptasi yang diterapkan oleh nalayan lanjut usia untuk mengatasi masalah dari segi faktor sosialbudaya serta bagaimana strategi adaptasi yang dilakukan dalam upaya mewujudkan suatu ketahanan sosial?

\subsection{Tinjauan Pustaka}

$D$ ada dekade terakhir, pertambahan jumlah lanjut usia di dunia berlangsung dengan pesat.

Pertumbuhan yang paling tinggi pada kelompok ini justru terjadi di sebagian besar negara berkembang dimana pada saat yang bersamaan tengah dihadapkan dengan persoalan-persoalan kependudukan yang cukup berat, akibat perubahan yang relatif cepat, baik dalam bidang pemerintahan, sistem ekonomi maupun sosial dan budaya. Berdasarkan pembagian lanjut usia didasarkan pada tingkatan usia, sebagian besar masyarakat juga memiliki persepsi dan mitos mengenai lanjut usia. Mitos-mitos lanjut usia tersebut pada dasarnya berasal dari sistem nilai budaya masyarakat, yang terkadang tidak sesuai dengan kenyataan yang sebenarnya.

Menurut Saul dan Nugroho, sebagaimana dikutip oleh Prayitno (1983), mitos-mitos dan kenyataan yang dialami tersebut dapat diuraikan sebagai berikut:

(1) Mitos kedamaian dan ketenangan; lanjut usia dapat santai menikmati hasil kerja dan jerih payahnya di masa muda dan dewasanya, segala rintangan dan goncanan kehidupan seolah-olah telah berhasil dilewati. Akan tetapi dalam kenyataannya para lanjut usia mengalami hal-hal seperti berikut, yaitu sering mengalami stres karena kemiskinan dan berbagai keluhan sakit, depresi, kekhawatiran, paranoid dan masalah psikotik.

(2) Mitos konservatisme dan kemunduran; pandangan bahwa lanjut usia pada umumnya bersifat konservatisme, tidak kreatif, menolak inovasi, beriorientasi dan merindukan masa silam, kembali bersifat seperti anak-anak, susah berubah, keras kepala dan cerewet. Namun dalam kenyataannya tidak semua orang lanjut usia berpikiran dan berperilaku demikian.

(3) Mitos berpenyakitan; lanjut usia sering dipandang sebagai masa degenerasi biologis yang disertai oleh penderitaaan akibat berbagai penyakit yang diderita seiring dengan proses penuaan. Pada umumnya proses penuaan memang disertai dengan menurunnya daya tahan tubuh dan metabolisme, sehingga sangat rawan terhadap penyakit.

Kajian mengenai orang lanjut usia menarik perhatian para ilmuwan sosial. Hal ini dimungkinkan karena aspek sosial budaya sering ditelaah, selain sudut pandang kesehatan itu sendiri. Lanjut usia merupakan gejala alami yang secara umum dialami oleh setiap individu. Seseorang pasti mengalami degenerasi dalam hidupnya, baik dari segi biologis, psikologis, sosial maupun ekonomi. 
Prayitno (1984) secara garis besar menyebut perubahan-perubahan dalam aspek tersebut antara lain: (1) fisik berupa kesehatan, kekuatan dan penampilan; (2) psikologis meliputi kecendrungan perasaan dan emosional; (3) sosial berkenaan dengan hubungan keluarga, relasi, status sosial, prestise, penghargaan dan penerimaan diri serta (4) ekonomi menyangkut hak milik, pendapatan atau pekerjaan.

Nugroho (1995) menyebutkan adanya perubahan-perubahan yang terjadi pada lanjut usia meliputi perubahan fisik, mental dan psikososial. Sementara Tony dan Hardywinoto (1999) memandang bahwa para lanjut usia mengalami adanya berbagai kemunduran fisik sehingga kemampuan bereaksi, seperti refleks maupun kemampuan menanggapi sesuatu cenderung menurun. Akan tetapi berbagai kenyataan lain menunjukkan bahwa kemampuan para lanjut usia tetap utuh sebagaimana terbukti dalam berbagai peneltian, sedangkan kemampuan di bidang emosi lebih dipengaruhi oleh kelambanan yang terjadi karena faktor fisik.

Secara biologis penduduk lanjut usia adalah penduduk yang mengalami proses penuaan secara terus menerus, yang ditandai dengan menurunnya daya tahan fisik yaitu semakin rentannya terhadap serangan penyakit yang dapat menyebabkan kematian. Hal ini disebabkan terjadinya perubahan dalam struktur dan fungsi sel, jaringan, serta sistem organ. Secara ekonomi, penduduk lanjut usia lebih dipandang sebagai beban dari pada sebagai sumber daya. Banyak orang beranggapan bahwa kehidupan masa tua tidak lagi memberikan banyak manfaat, bahkan ada yang sampai beranggapan bahwa kehidupan masa tua, seringkali dipersepsikan secara negatif sebagai beban keluarga dan masyarakat.

Dari aspek sosial, penduduk lanjut usia merupakan satu kelompok sosial sendiri. Di negara Barat, penduduk lanjut usia menduduki strata sosial di bawah kaum muda. Hal ini dilihat dari keterlibatan mereka terhadap sumber daya ekonomi, pengaruh terhadap pengambilan keputuan serta luasnya hubungan sosial yang semakin menurun.
Akan tetapi di Indonesia Ada juga lanjut usia yang memandang usia tua dengan sikap-sikap yang berkisar antara kepasrahan yang pasif dan pemberontakan, penolakan, dan keputusasan.

Studi yang dilakukan oleh Cohen (1984:244) mengenai pengalaman lanjut usia menunjukkan bahwa walaupun pikiran orang muda bekerja lebih cepat, orang lanjut usia memecahkan masalah yang sangat kompleks dengan pengalaman. Kemampuan untuk memecahkan masalah yang didasarkan pada kepercayaan diri dan pengalaman dari orang lanjut usia dapat menghadiri kecenderungan untuk mengeluh dengan kesehatan fisik dan depresi di masa tua, serta tetap mudah berinteraksi dengan masyarakat.

Para lanjut usia memerlukan strategi adaptasi untuk menghadapi berbagai permasalahan dan kesulitan hidup yang dialami. Konsep strategi adaptasi merujuk pada suatu rencana tindakan selama rentang waktu tertentu oleh sekelompok atau sekumpulan orang tertentu untuk menyesuaikan diri atau mengatasi tekanan yang bersifat internal atau eksternal (Smith, 1986). Semula adaptasi merupakan konsep yang digunakan dalam teori-teori biologi mengenai evolusi genetik untuk menunjukkan perubahan psikologis atau perilaku yang menghasilkan kesempatan untuk bertahan hidup dalam sebuah lingkungan tertentu. Secara lebih luas, istilah itu telah diterapkan pada perilaku manusia dan evolusi sosial budaya. Dalam kaitan ini, kebudayaan merupakan instrumen adaptasi manusia yang paling penting, yaitu sebagai suatu perluasan psikologinya dan instrumen untuk mempertahankan suatu hubungan yang langgeng dengan komunitasnya (Cohen, 1969).

Strategi adaptasi yang dilakukan oleh nelayan lanjut usia untuk pemenuhan ekonomi rumah tangga nelayan dianggap bisa mewujudkan suatu ketahanan sosial. Secara sederhana, ketahanan sosial suatu komunitas sering dikaitkan dengan kemampuan dalam mengatasi resiko akibat perubahan sosial, ekonomi, politik yang mengelilinginya (Betke, 2002). 
Suatu komuniti memiliki ketahanan sosial bila pertama, ia mampu melindungi secara efektif anggotanya termasuk individu dan keluarga yang rentan dari gelombang perubaha sosial yang mempengaruhinya; kedua, mampu melakukan investasi sosial dalam jaringan sosial yang menguntungkan; dan ketiga, mampu mengembangkan mekanisme yang efektif dalam mengelola konflik dan kekerasan (Rochman, 2002; Hikmat, 2002).

Pengembangan kebijakan, strategi dan program serta indikator ketahanan sosial menjadi penting dan strategis, dengan alasan (1) Ketahanan sosial merupakan salah satu indikator dari pembangunan yang berkelanjutan; (2) Ketahanan sosial merupakan salah satu dampak yang diharapkan dari program perlindungan sosial yang dikelola oleh pemerintah (formal public schemes) dan masyarakat (traditional or informal private or community based schemens); (3) Ketahanan sosial merupakan salah satu sub sistem dalam hubungan kontingensi (interaksi antar sub sistem makro, meso dan mikro) dalam sistem pembangunan nasional; (4) Ketahanan sosial dapat diuji hubungan kausalitasnya diantara : (1) ketahanan sosial (dependent variabel); (2) pemberdayaan masyarakat, inklusi sosial dan jaminan sosial (intervening variabel) dan (3) penguatan modal sosial (independet variable); (5) Kontributor positif dan negatif terhadap ketahanan sosial masyarakat adalah kondisi kualitas hidup dan kesejahteraan penduduk miskin, rentan dan marginal (termasuk yang dikategorikan PMKS) dan (6) Ketidaktahanan sosial yang paling parah dapat ditunjukkan oleh kondisi kemiskinan kronis (fakir miskin dan penyadang masalah sosial) yang merupakan sasaran utama Pembangunan Kesejahteraan Sosial (Hikmat, 2002).

\subsection{Tujuan Dan Manfaat Penelitian \\ $\begin{array}{cr}\text { enelitian ini } & \text { bertujuan } \\ \text { memberikan } & \text { gambaran } \\ \text { strategi }\end{array}$}

masyarakat nelayan dalam menghadapi lanjut usia untuk mewujudkan ketahanan sosial, yaitu mengenai (1) masalah riil yang dihadapi nelayan lanjut usia, (2) pilihan strategi adaptasi nelayan lanjut usia yang diterapkan untuk memecahkan masalah dikaitkan dengan faktor sosial budaya, (3) upaya strategi adaptasi untuk mewujudkan suatu ketahanan sosial dalam masyarakat.

Adapun manfaat penelitian ini adalah sebagai masukan terhadap pemerintah daerah kabupaten Pasaman Barat mengenai kondisi faktual masyarakat nelayan lanjut usia yang dianggap memiliki kerentanan sosial sehingga berdampak kepada masalah sosial yang ada dalam masyarakat nelayan tersebut. Selain itu, memberikan rekomendasi terkait dengan upaya yang dilakukan masyarakat nelayan lanjut usia untuk mengantisipasi kemiskinan dengan strategi adaptasi yang selalu dilakukan sehingga diperlukan upaya pemberdayaan masyarakat nelayan terutama pihak nelayan lanjut usia sendiri untuk menjaga ketahanan sosial di dalam masyarakat.

\subsection{Metode Penelitian}

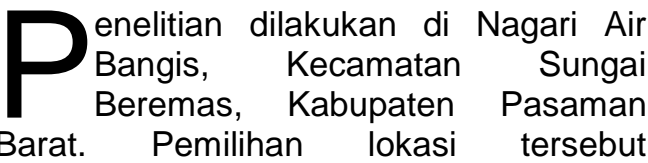
dikarenakan kondisi faktual kehidupan para nelayan lanjut usia yang telah melewati masa usia produktif dengan berbagai aktivitas yang dilakukan oleh nelayan lanjut usia sebagai bentuk strategi adaptasi dalam menghadapi masa lanjut usia yang diklasifikasi berdasarkan jenis pekerjaan di bidang atau di luar kenelayanan. Selain itu, jumlah penduduk lanjut usia di lokasi penelitian tergolong mampu mempengaruhi kehidupan masyarakat nelayan secara keseluruhan, yaitu sekitar $12 \%$. Hal ini akan memperlihatkan relevansi antara pilihan-pilihan strategi yang dimungkinkan sebagai upaya adaptasi nelayan lanjut usia dalam mengantisipasi berbagai perubahan yang terjadi dalam kehidupan masyarakat nelayan secara keseluruhan sehingga mampu mewujudkan suatu ketahanan sosial. 
dengan $\begin{array}{cr}\text { Penelitian ini dilaksanakan } \\ \text { menggunakan pendekatan }\end{array}$ kualitatif melalui studi kasus. Tipe studi kasus yang digunakan yaitu studi kasus deskripstif dimana dalam penggunaannya, peneliti studi kasus perlu memusatkan perhatian kepada aspek holistik dan bermakna dari peristiwaperistiwa kehidupan nyata seperti siklus kehidupan seseorang, proses-proses organisasional dan manajerial, perubahan lingkungan sosial. Studi kasus terutama pada masa lanjut usia bagi masyarakat nelayan secara sosial budaya ditentukan berdasarkan tingkat produktivitas yang dihasilkan, apakah masih aktif mencari ikan di lautan lepas atau hanya sepanjang pantai. Batasan usia produktif berpengaruh secara langsung terhadap berkurangnya pendapatan nelayan. Kenyataan ini menyebabkan munculnya berbagai permasalahan yang dialami nelayan lanjut usia, baik dari aspek ekonomi, psikologis, sosial dan budaya.

Dalam mengumpulkan data, peneliti menggunakan 3 (tiga) teknik pengumpulan data, yaitu: (1) Wawancara bebas dan mendalam, (2) Observasi dan (3) Studi Kepustakaan. Informan adalah pihak yang dapat memberikan informasiinformasi tentang gejala-gejala yang terlihat dan diartikan sesuai dengan kebudayaan yang mereka punyai. Tindakan-tindakan yang tampak dalam menanggapi gejala-gejala tersebut diamati untuk dianalisis apakah tindakan tersebut sesuai dengan pemberian makna dari pelaku atau informan terhadap gejala yang bersangkutan (Bungin, 2001).

Pemilihan informan diambil secara purposive (sengaja), dimana pengambilan jumlah informan yang bersifat tidak acak dan diambil berdasarkan pertimbangan-pertimbangan tertentu yang dapat memberikan informasi sesuai dengan masalah yang diteliti. Selain itu, untuk menemukan para informan menggunakan teknik bola salju (snow ball). Cara bola salju (snow ball) dilakukan apabila sudah mendapatkan informasi dari informan pertama dan peneliti menginginkan informan selanjutnya, maka peneliti bisa memperoleh informasi tersebut dari informan pertama. Hal tersebut bisa dilakukan kepada informan-informan lain untuk mendapatkan informan yang peneliti inginkan. Dalam pemilihan informan, akan dibagi dalam dua kelompok, yaitu informan kunci dan informan biasa. Menurut Bungin (2001) bahwa penentuan siapa yang harus menjadi informan kunci melalui beberapa pertimbangan di antaranya: orang yang bersangkutan memiliki pengalaman pribadi sesuai dengan permasalahan yang diteliti, usia orang yang bersangkutan telah dewasa, orang yang bersangkutan sehat jasmani dan rohani, bersifat netral dan memiliki pengetahuan yang luas mengenai permasalahan yang diteliti. Informan kunci yang dipilih yaitu nelayan yang telah masuk kategori lanjut usia. Sedangkan wawancara dengan informan biasa, yaitu keluarga-keluarga nelayan lanjut usia dan tokoh masyarakat seperti wali nagari dan wali jorong.

Data-data yang telah dikumpulkan oleh peneliti termasuk juga catatan lapangan dikelompokkan oleh peneliti atas dasar aktivitas khusus yang ada dan diteliti. Kemudian dari pengelompokkan data tersebut, data-data itu kemudian diabstraksikan dan dikaitkan satu dengan lainnya sebagai satu kesatuan kejadian dan fakta yang terintegrasi. Dari abstraksi tersebut maka akan tampak pranata sosial yang berlaku di wilayah atau komuniti tersebut (Bungin, 2001). Dalam menganalisis tentunya selalu terkait dengan konsep yang telah dipelajari sebelumnya. Sehingga dari hasil analisis akan tampak kesesuaian dari data yang diperolehnya dengan konsep yang dipelajarinya atau akan berbeda dengan konsep yang dipelajarinya karena masalah sosial akan selalu berbeda antara satu masyarakat dengan masyarakat lainnya. Setelah itu disusun sesuai dengan kategori-kategori dan kemudian disimpulkan. Apabila dalam kesimpulan masih menimbulkan keraguan maka dilakukan pengkategorian ulang hingga seluruh data yang telah berhasil dikumpulkan dianggap sesuai dengan tujuan penelitian. Temuan di lapangan akan diolah dengan data yang didapat dari literatur dan akan disajikan dalam suatu karya etnografi deskriptif. 
1.6 Hasil Dan Pembahasan

1.6.1 Gambaran Umum Nagari Air Bangis, Kec. Sungai Beremas, Kab. Pasaman Barat

$\mathrm{N}$ agari Air Bangis merupakan ibu kota kecamatan Sungai Beremas, Kabupaten Pasaman Barat dan satu-satunya nagari di wilayah tersebut. Nagari Air Bangis adalah sebuah Nagari yang terletak di tepi pantai barat Sumatera Barat dengan batas batas sebagai berikut: Sebelah Utara berbatasan dengan Kecamatan Silaping, Sebelah Selatan berbatasan dengan Kecamatan Paru, Sebelah Timur berbatasan dengan Nagari Parit dan sebelah Barat berbatasan dengan Kecamatan Batahan.

Di kenagarian Air Bangis ini terdapat 15 jorong yang masingmasingnya berada dipinggir pantai, diantaranya adalah: Jorong Pasar Satu, Jorong Pasar Suak, Jorong Pokan, Jorong Kampung Padang Utara, Jorong Kampung Padang Selatan, Jorong Pasar Baru Barat, Jorong Pasar Baru Timur, Jorong Pasar Baru Utara, Jorong Pasar Muara, Jorong Pasar Dua Suak, Jorong Silawi Timur, Jorong Silawi Tengah, Jorong Pulau Panjang, Jorong Pigogah Pati Bubur dan Jorong Ranah Panantian

Nagari Air Bangis juga terkenal dengan istilah nan sambilan, yaitu berupa sembilan buah pulau yang berada disekitar kenagarian tersebut diantaranya adalah: (1) Pulau tamiang, (2) Pulau talua, (3) Pulau pigago, (4) Pulau unggas, (5) Pulau ikan, (6) Pulau harimau, (7) Pulau nibung, (8) Pulau panjang, dan (9) Pulau pangkal.

Nagari Air Bangis memiliki ketinggian tempat berkisar $2 \mathrm{~m}$ dari permukaan laut dengan suhu rata-rata sekitar $23^{\circ} \mathrm{C}-24^{\circ} \mathrm{C}$ dengan rata-rata curah hujan $43 \mathrm{~mm}-55 \mathrm{~mm} / \mathrm{bulan}$, dengan posisi geografis $00^{\circ} \quad 09^{\circ}-00^{\circ} 31^{\circ}$ Lintang Utara/Lintang Selatan, $99^{\circ} 10^{\circ}-90^{\circ} 34^{\circ}$ Bujur Timur. Wilayah ini terdiri dari dataran rendah, dengan tinggi pesisir pantai yang rendah dengan luas wilayah 194,205 Ha.

Berdasarkan penggunaan lahan dan luas wilayah tersebut menjelaskan bahwa penggunaan lahan perumahan dan sepanjang pantai mendominasi luas wilayah di Nagari Air Bangis, Kec. Sungai Beremas, Kab. Pasaman Barat. Nagari ini memiliki garis pantai yang cukup panjang dan juga memiliki keindahan dari aspek pemandangan lautnya.

\section{$\mathrm{M}$}

1.6.2 Sejarah Nagari enurut cerita masyarakat setempat, asal usul Nagari Air Bangis berasal dari kata aie bangai. Aie bangai ini terdapat aliran sungai yang langsung bermuarakan ke laut ini, dulunya memiliki kondisi air yang seperti mendidih dan kurang bersih. Asal usul dari nama nagari tersebut menurut informasi dari masyarakat bahwa nagari ini berasal dari kata bangih yaitu sebuah nama pohon bangei atau sejenis pohon yang hidup di pinggiran sungai. Oleh karena itu sungai tersebut diberi nama aie bangei. Dengan beberapa generasi yang secara terus menerus mengalami perubahan yang mana pada akhirnya kata aie bangei tersebut juga mengalami perubahan menjadi aia bangih yang sekarang disebut (Air Bangis).

\subsubsection{Keadaan Demografi}

$\mathrm{B}$ erdasarkan database desa/kelurahan Nagari desa/kelurahan Nagari Air Bangis sebanyak 21.112 jiwa orang, dengan penduduk laki-laki berjumlah 10.463 jiwa dan penduduk perempuan 10.649 jiwa orang. Jumlah kepala keluarga (KK) adalah $5.233 \mathrm{KK}$. Selain itu, jumlah penduduk miskin di wilayah Nagari Air Bangis berjumlah 4.749 KK (19.997 jiwa).

Berdasarkan hasil wawancara diperoleh bahwa jumlah penduduk terbanyak di Nagari Air Bangis yang dikategorikan pada usia produktif berada pada tingkat umur antara 20 tahun hingga 50 tahun. Hal tersebut terkait erat dengan pekerjaan sebagai nelayan, terutama menjadi nelayan buruh yang menjadi jumlah yang terbesar di wilayah ini dimana pekerjaan nelayan ditekuni oleh masyarakat mulai dari usia muda hingga lanjut usia.

\subsubsection{Mata Pencaharian}

alam pemenuhan kebutuhan hidup masyarakat di Nagari Air Bangis, baik kebutuhan dasar seperti 
kebutuhan sandang, pangan dan papan maupun kebutuhan sekunder seperti kebutuhan pendukung lainnya sangat diperlukan mata pencaharian untuk mencapai usaha tersebut. Dalam pemenuhan kebutuhan tersebut, di dalam masyarakat mempunyai mata pencaharian yang beragam/bervariasi. Demikian juga dengan masyarakat Nagari Air Bangis yang memiliki beragam mata pencaharian. Bahwa sebagian besar penduduk di Nagari Air Bangis bermata pencaharian sebagai petani, buruh dan nelayan, terutama nelayan buruh sebanyak 1000 (21\%). Salah satu penyebabnya adalah kondisi wilayah Nagari Air Bangis yang terletak memanjang di garis pentai daerah Pasaman Barat.

\subsubsection{Tingkat Pendidikan}

$\mathrm{P}$ endidikan merupakan kebutuhan utama masyarakat di Nagari Air Bangis sebagai usaha untuk menambah ilmu pengetahuan mereka dan juga mengangkat pada derajat yang lebih tinggi. Kesadaran masyarakat di Nagari Air Bangis terhadap pentingnya pendidikan cukup tinggi dimana sebagian besar masyarakatnya sudah mengenyam pendidikan pada tingkat SMP dan SMA. Meskipun demikian, sebagian masyarakatnya juga ada yang menamatkan pendidikan hanya pada tingkat SD.

Tingkat pendidikan di Nagari Air Bangis sudah cukup tinggi. Hal tersebut diperlihatkan melalui jumlah penduduk yang telah menamatkan pendidikan SD, SMP dan SMA sebanyak 11.920 (96\%). Meskipun demikian, diperoleh juga terdapat penduduk yang tidak menamatkan pendidikan SD (2\%). Pada umumnya, mereka yang tidak menamatkan pendidikan SD dikarenakan faktor ekonomi dan kesempatan.

\subsubsection{Sarana Sosial: Agama,} Kesehatan
rdasarkan database Potensi erdasarkan database Potensi Bangis pada tahun 2010, bahwa jumlah penduduk berdasarkan agama sebagian besar penduduk menganut agama Islam sebanyak 21.112 (100\%), yang memiliki tempat peribadatan, yaitu mesjid sebanyak 9 unit dan mushalla sebanyak 9 unit.

Selain agama, masalah kesehatan menjadi hal yang sangat penting bagi kehidupan masyarakat Air Bangis. Penyakit yang sering menyerang masyarakat adalah penyakit TBC dan Malaria. Untuk fasilitas kesehatan yang ada di nagari Air Bangis adalah Puskesmas sebanyak 1 unit, Poliklinik/Pustu sebanyak 2 unit, Polindes sebanyak 5 unit dan Posyandu sebanyak 11 unit.

\subsubsection{Pola Pemukiman Nagari Air Bangis}

P ola pemukiman adalah wujud dari bentuk pemukiman pada suatu daerah yang meliputi pola letak tempat tinggan dan bentuk rumah di pemukiman tersebut. Pola letak pemukiman di Nagari Air Bangis tidak berbeda jauh dengan pola pemukiman wilayah pesisir di daerah lain, dimana rumah-rumah membentang sepanjang pantai di pesisir pantai Pasaman Barat.

Pola pemukiman Nagari Air Bangis yang mengikuti garis pantai dimulai dari jorong Kampung Padang Utara, kemudian dilanjutkan menuju jorong Kampung Padang Selatan, jorong Pasar Suak, Pasar Muara, Pasar Baru dan Pasar Pokan. Untuk jorong lainnya berada di sepanjang perbukitan yang berada di seberang garis pantai. Untuk menuju Nagari Air Bangis, dapat ditempuh dengan kendaraan beroda dua dan empat dengan sarana jalan yang cukup baik sehingga dapat ditempuh selama 5 jam perjalanan dari ibu kota Sumatera Barat, yaitu kota Padang. Kepemilikan rumah yang berada di sekitar pantai adalah sebagian besar dimiliki oleh rumah tangga nelayan buruh dan juga pedagang ikan berskala kecil. Pada umumnya, bentuk rumah di Nagari Air Bangis, terutama kampung-kampung di sekitar pantai terdiri dari rumah tidak permanen dan semi permanen dan hanya beberapa rumah saja yang permanen, yaitu sekitar 5-10 rumah. Untuk rumahrumah yang berada di sekitar jalan utama yang menghubungkan antar korong di kecamatan Ulakan Tapakis, keadaannya 
lebih baik dari rumah yang ada di dekat pantai. Biasanya rumah-rumah di wilayah ini dihuni oleh pedagang ikan dengan skala yang lebih besar dibandingkan dengan pedagang yang ada di pinggir pantai.

Berdasarkan observasi (melalui pengamatan), terdapat beberapa rumah di pemukiman sekitar wilayah pantai (5-10 rumah) yang dihuni oleh para nelayan yang tidak layak untuk menjadi tempat tinggal. Rumah mereka hanya beralaskan pasir pantai dan berdindingkan kayu dan juga atapnya terbuat dari seng yang sudah berkarat dan berlubang.

Di sekitar pemukiman nelayan, terdapat 2- 4 warung makanan yang selalu dipenuhi oleh para nelayan buruh, terutama sekali ketika mereka sudah selesai melaksanakan aktivitas penangkapan ikan seperti memukat dan juga pada saat terjadinya badai (cuaca tidak baik). Aktivitas yang biasa mereka lakukan adalah berdiskusi tentang aktivitas penangkapan ikan, bermain domino/kartu dan hanya sekedar minum kopi.

\subsubsection{Sistem Kekerabatan dan Pemerintahan Adat Nagari Air Bangis}

$\mathrm{M}$ asyarakat Nagari Air Bangis menganut sistem kekerabatan matrilineal, yakni kekerabatan mengacu kepada garis keturunan perempuan. Nagari Air Bangis adalah sebuah nagari terbuka dan sangat pluralistik-heterogen yang terdiri dari enam buah suku diantaranya adalah:

1. Suku Malayu (Suku Raja) dengan beberapa pimpinan yaitu Rang Tuo Rajo, Dt. Bandaro, Dt. Magek Tigarang dan Dt. Mudo.

2. Suku Tanjung dengan pimpinan Dt. Rajo Amat

3. Sikumbang dengan pimpinan Dt. Rajo Mau

4. Chaniago beberapa pimpinan Dt. Rajo Sampono \& Dt. Tan Maliputi.

5. Mandahiling (lubis-Sumut) yang dipimpin oeh Dt. Rajo Todung

6. Jambak yang dipimpin oleh Dt. Rangkayo Mardeso.
Air Struktur Pemerintahan Adat Nagari Pucuk Adat/Daulat Rajo kenagarian Air Bangis yang berasal dari keturunan rajaraja yang memerintah Air Bangis sejak dahulu kala, secara langsung menjabat sebagai ketua KAN Air Bangis. Secara ekplisit dengan adanya Pucuk Adat, Nagari Air Bangis termasuk kedalam stelsel adat Koto Piliang. Dimana fungsi Pucuk Adat disini menjalankan fungsi pengukuhan/penetapan. Jika dalam suatu rapat ninik mamak sudah melahirkan suatu kesepakatan, maka Pucuk Adat kemudian menetapkan keputusan rapat tersebut. Apabila keputusan yang sudah dikukuhkan tersebut ingin dirubah, maka haruslah dilakukan dalam suatu rapat bersama pula.

Nagari Air Bangis adalah nagari yang sangat plural dan heterogen. Tidak hanya saat ini nagari air Bangis yang didatangi oleh pendatang. Tetapi sejak dahulu kala nagari Air Bangis sudah merupakan pusat perdagangan sebagaimana layaknya daerah-daerah pesisir pantai lainnya. Perkawinan penduduk asli dengan pendatang kemudian melahirkan keturunan yang kemudian menetap di Nagari Air Bangis. Meskipun demikian, dari data-data yang didapat dilapangan semua pendatang secara sadar menundukkan diri kepada hukum adat Minangkabau. Seperti marga Lubis yang kemudian menjadi Suku Mandahiling di Nagari Air Bangis. Kemudian seiring dengan perjalanan waktu, keturunan-keturunan dari pembauran masyarakat Air Bangis tersebut melebur diri kedalam tatanan adat yang sangat unik sekali.

Keterbukaan Nagari Air Bangis terhadap pendatang tercermin dalam ketentuan adat yang sudah berlaku sejak dulu sekali. Menurut Adat yang berlaku di Nagari Air Bangis dikenal satu konsep, yaitu: "Dagang Darat Basandaran, Dagang Laut batambatan". Artinya, setiap anak dagang (pendatang) yang datang ke Nagari Air Bangis, sudah ada tempat dimana ia akan berlindung (tepatan), sehingga dengan demikian tidak akan ada anak dagang yang akan terlantar. Asalkan dipenuhi syarat-syarat yang ditentukan oleh tepatannya tersebut. Atau secara 
umum disebutkan dengan istilah "Datang Tampak Muka, Pulang Tampak Punggung".

\subsection{Aktivitas Ekonomi Perikanan Masyarakat \\ Ativitas ekonomi perikanan yang dilakukan oleh nelayan pada Uumumnya dilakukan secara} berkelompok tetapi ada juga yang melakukannya secara perorangan. Kegiatan tersebut sebagian besar dilakukan oleh pihak laki-laki yang berumur diatas 15 tahun. Pendapatan nelayan di Nagari Air Bangis berkisar antara Rp.25.000,- hingga Rp. 100.000,-. Pendapatan nelayan termasuk rendah dikarenakan sebagian besar nelayan di Nagari Air Bangis tersebut adalah nelayan buruh (60\%). Aktivitas penangkapan ikan pada masyarakat nelayan Nagari Air Bangis, yaitu aktivitas membagan (kapal bagan), memayang, memukat dan menjaring.

Aktivitas

membagan menggunakan sebuah kapal kayu (bagan) dengan panjang $\pm 15 \mathrm{~m}$ dan lebar $\pm 3 \mathrm{~m}$. Menggunakan mesin disel yang biasa dipakai oleh truk Fuso yang telah dimodifikasi sedemikian rupa. Pada sisisisi bagan terdapat kayu-kayu penyeimbang (cadik) yang sekaligus merupakan tempat jaring di ikat. Penangkapan ikan dilakukan dengan bantuan cahaya lampu yang ditempatkan disekeliling body bagan. Ketika ikan-ikan sudah tertarik untuk mendekat, maka disaat itu jaring dijatuhkan. Dewasa ini, alat pendeteksi ikan yang digunakan pada Bagan, sudah memakai alat deteksi yang memakai gelombang elektronik (Sonar). Menurut keterangan masyarakat, di Air Bangis saat ini terdapat \pm 150 buah Bagan dimana harga dari sebuah bagan adalah \pm Rp. 100.000,-. Ikan-ikan hasil tangkapan ikan biasanya dijual dalam keadaan hidup maupun dalam keadaan kering, setelah diolah dipengeringan ikan.

Dalam beroperasi, Bagan sangat tergantung kepada musim. Di Air Bangis musim penangkapan ikan tersebut dikenal atas dua musim yaitu musim kelam dan musim terang. Hitungan musim kelam dan musim terang tersebut mengikuti arah rotasi bulan. Artinya ketika bulan muncul pada beberapa waktu tertentu dan cahayanya terang, maka Bagan tidak beroperasi. Karena alat bantu pengumpul ikan berupa lampu-lampu, tidak akan berguna. Perhitungan waktu antara musim kelam dan musim terang adalah mengikuti penanggalan bulan Arab. Secara garis besarnya, dalam setiap bulan, musim gelap kira-kira 3 minggu dan musim terang kira-kira 1 minggu (6 hari). Dalam pengetahuan nelayan Air Bangis, secara umum musim terang dimana ada bulan purnama adalah sekitar tanggal 13, 14, 15, dan 16 setiap bulannya. Sedangkan musim gelap adalah mulai tanggal 18 sampai dengan tanggal 12 bulan depannya. Selama bulan kelamlah Bagan dapat beroperasi. Sementara hari-hari dibulan terang, dimamfaatkan untuk memperbaiki alat tangkap.

Bagan memperkerjakan $\pm 10 \mathrm{~s} / \mathrm{d}$ 15 orang $A B K$ dengan tugas tugas tertentu dan dengan strata tertentu. Tatacara penggajian dan pembagian hasil dilakukan dengan cara musyawarah. Setiap hari para ABK bagan mendapatkan sejumlah uang dari pengusaha Bagan. Guna uang tersebut adalah untuk kebutuhan harian para ABK ke Laut. Atau diistilahkan untuk pembeli rokok dan supermi. Tetapi yang diberikan uang rokok dan supermie tersebut hanyalah ABK tetap di Bagan tersebut. Jumlah uang harian tersebut rata-rata $\mathrm{Rp}$. 20.000,-.

Pembagian hasil keseluruhan dilakukan pada saat mulainya musim terang atau sekali musim kelam. Dimana perhitungannya adalah hasil bersih selama musim tangkap/musim kelam/selama bagan beroperasi dibagi dua. Setengah dari hasil tersebut untuk pengusaha Bagan, sedangkan setengannya lagi dibagi rata terhadap seluruh ABK tetap. Disamping itu kedudukan seseorang dalam sebuah bagan, juga ikut menentukan hasil yang didapatkannya selama bagan beroperasi atau sekali musim kelam. Hal ini disebabkan karena adanya bonus-bonus yang diberikan oleh pengusaha bagan kepada orang-orang yang mempunyai jabatan tertentu. Pada beberapa pengusaha bagan, meskipun bagan tidak 
beroperasi, ABK tetap bagan miliknya tetap digaji atau tetap diberikan uang rokok dan uang supermi. Hal ini dimaksudkan untuk membantu kehidupan para ABK. Setiap Bagan setelah beroperasi setiap harinya selalu menepi kepantai. Hal ini dilakukan jika daerah tempat Bagan tersebut menagkap ikan, tidak begitu jauh dari daerah Air Bangis. Artinya, setiap jam 16.00 Wib Bagan berangkat dan kira-kira jam 10.00 Wib besok paginya sudah merapat lagi. Setiap malamnya, rata-rata ABK Bagan menjatuhkan jaring sebanyak dua kali untuk menangkap ikan yang sudah berkumpul disekeliling bagan. Biasanya penjatuhan jaring dilakukan pada waktu tengah malam. Pembagian jabatan tersebut adalah Tungganai Bagan. Tungganai Bagan adalah merupakan jabatan tertinggi disebuah bagan. Tungganai Bagan merupakan wakil dari pemilik bagan dalam menjalankan usahanya. Tungaganai Bagan berhak untuk menjual ikan hasil tangkapan dilautan dan berhak untuk menentukan, kemana arah penangkapan ikan akan dilakukan. Dalam pembagian hasil tangkapan sekali musim kelam, Tungganai Bagan mendapatkan bagian yang sama dengan ABK lainnya. Tetapi disamping itu, Tungganai Bagan juga mendapatkan bonus dari pengusaha Bagan. Apik Tungganai Apik Tungganai adalah merupakan wakil dari Tungganai Bagan. Dalam perekrutannya, Apik Tungganai ditunjuk oleh Tungganai Bagan yang bersangkutan. Disamping bertugas sebagai wakil dari Tungganai Payang, perekrutan seorang Apik Tungganai juga dimaksudkan sebagai salah satu upaya kaderisasi, untuk melahirkan TungganaiTungganai yang baru. Dalam pembagian hasil tangkap, Apik Tungganai juga mendapatkan bonus lain, disamping persentase hasil yang sama dengan ABK lain. Tetapi bonus tersebut diberikan oleh Tungganai, bukan oleh pengusaha Bagan. Kepala Kamar Mesin. Jabatan Kepala Kamar Mesin (KKM) adalah jabatan yang cukup fital dalam sebuah Bagan. Karena KKM yang langsung bertanggungjawab atas kelancaran operasi Bagan. Dalam pembagian hasil,
KKM mendapatkan bonus tambahan dari pengusaha Bagan disamping persentase yang sama dengan $A B K$ lain.

$A B K$ Lain. Para ABK lain untuk secara umum bertugas membantu kelancaran operasi Bagan. Ketika teknologi yang digunakan pada Bagan sudah mulai berkembang, tugas-tugas ABK semakin ringan. Kalau dulu pekerjaan para $\mathrm{ABK}$ juga termasuk menarik jaring yang sudah dipenuhi ikan, sekarang tugas tersebut sudah diambil alih oleh mesin. Tugas-tugas lain diantaranya adalah untuk mengumpulkan dan memilih ikan yang sudah tertangkap. Dalam pembagian hasil, ABK hanyalah mendapatkan dari hasil pembagian rata sekali musim tangkap/musim kelam tampa bonus lain dari pengusaha bagan.

ABK Honor. ABK Honor adalah $A B K / p e k e r j a$ yang tidak tetap pada sebuah Bagan. Kehadirannya untuk bekerja, tergantung kepada kemauan mereka. Gaji yang didapat, disesuaikan dengan hasil tangkapan pada hari ketika ia bekerja. ABK Honor, tidak mendapatkan bagian dari pembagian hasil akhir musim tangkap/musim kelam. Demikian juga ABK Honor tidak mendapatkan bonus-bonus.

Aktivitas

memayang menggunakan Boat Ts, yaitu sebuah kapal kayu dengan panjang $\pm 10 \mathrm{~m}$ dengan lebar $\pm 2 \mathrm{~m}$. Dilengkapi dengan mesin Yanmark/mesin yang biasa dipakai pada mollen (pengaduk semen) yang telah dimodifikasi. Alat tangkap ikan yang digunakan adalah berupa Jaring Benam, jaring udang atau jaring suaso. Pada bot Ts, ABK yang mengoperasikannya paling banyak 4 orang dan paling sedikit 3 orang. Masing-masing ABK mempunyai tugas sendiri-sendiri. Jaring ditebar ketika Bot Ts dalam keadaaan mundur. Satu orang ABK bertugas menebar jaring, satu orang bertugas untuk mengarahkan Baot Ts dengan menggunakan dayung dan yang lainnya bertugas sebagai nakoda. Boat Ts beroperasi sejak sore hari sampai jam 09.00 Wib setiap harinya. Ikan hasil tangkapan, bisa dijual langsung kepada pedagang-pedagan pengumpul yang langsung menyambangi kelautan ataupun dijual sendiri ke TPI. 
Aktivitas Memukat menggunakan perahu layar. Perahu Layar tidak menggunakan tenaga pendorong mesin, tetapi menggunakan layar untuk bergerak. Disamping itu pada saat-saat tertentu juga menggunakan dayung. Alat tangkap yang digunakan adalah Jaring hanyut, jaring udang atau pukat ular. ABK yang mengoperasikan perahu layar ini paling banyak dua orang. Jaring ditebar seiring dengan gerakan perahu. Kemudian ketika jaring hendak diangkat, jangkar dibuang kelaut.

Aktivitas memancing menggunakan Perahu Dayung. Perahu dayung digunakan oleh pedagangpedagang ikan yang tidak memiliki Boat Tempel dalam usahanya mengumpulkan ikan. Kemudian setelah ikan terkumpul, ikan-ikan tersebut kemudian dijual ke TPI.

\subsection{Strategi Adaptasi Masyarakat Nelayan dalam Menghadapi Masa Lanjut Usia}

1.8.1 Kehidupan Nelayan Lanjut Usia

A. Masalah-masalah yang dihadapi Keluarga Nelayan Lanjut Usia

D ermasalahan yang dialami keluarga lanjut usia pada masyarakat pedesaan umumnya berkisar pada berkurangnya aktivitas pekerjaan yang menyebabkan penurunan pendapatan. Mata pencaharian apapun yang ditekuni oleh anggota masyarakat memiliki batas masa produktif tertentu, sekalipun dalam rentang waktu yang berbeda. Pekerjaan sebagai petani dan nelayan tetap memiliki keterbatasan ketika seseorang sudah mencapau lanjut usia. Berkurangnya pendapatan karena seseorang sudah menjadi pensiun atau mengurangi aktivitas bagi nelayan, petani menyebabkan seseorang yang sudah lanjut usia untuk dapat memenuhi kebutuhan hidupnya secara maksimal, terlebih bagi yang menghentikan pekerjaan sama sekali. Kondisi ini menyebabkan beberapa keluarga lanjut usia cenderung mengefektifkan fungsi kerabat dalam mengantisipasi pemenuhan kebutuhan ekonomi.

Permasalahan yang dialami keluarga nelayan lanjut usia pada secara umum tidak berbeda dengan pekerjaan lain pada umumnya, yaitu ketidakmampuan memenuhi kebutuhan ekonomi sebagai akibat dari berkurangnya kemampuan fisik dan terbatasnta dalam mendapatkan pekerjaan utama. Akan tetapi nelayan memiliki strategi tertentu untuk tetap dapat melakukan aktivitas pekerjaan. Pekerjaan sebagai nelayan yang sangat mengandalkan kekuatan fisik menempatkan nelayan yang sudah melewati batas usia produktif sulit untuk dapat bersaing dengan nelayan muda. Faktor kemampuan fisik ini berpengaruh terhadap aspek-aspek lain dalam kehidupan nelayan seperti transisi psikososial akibat hilangnya pekerjaan utama yang sudah bertahun-tahun ditekuni, hilangnya kepercayaan dari pemilik modal ataupun kesehatan yang sudah menurun. Sungguhpun demikian, nelayan lanjut usia tetap berupaya mengurangi ketergantungan pada kerabat.

Permasalahan lain yang dialami keluarga lanjut usia adalah munculnya rasa kesepian akibat berkurangnya hubungan intrapribadi dalam keluarga maupun kelompok kerabat. Ketika pasangan suami istri tengah mencapai usia lanjut, secara psikologis mereka merasa khawatir akan hilangnya suasana kebersamaan yang berlangsung selama bertahun-tahun. Anak-anak yang semuka tinggal bersama satu-persatu meninggalkan orangtua karena membentuk keluarga baru.

Gejala ini dapat diasumsikan sebagai suatu perubahan bentuk keluarga yang secara riil mulai tampak pada masyarakat pedesaan pesisir. Menurut Le play, salah satu tipe keluarga yang dominan dan dikembangkan pasangan suami istri pada perkembangan sekarang adalah nuclear family (Tangdilintin, 1993:3). Dalam kaitan yang khusus, gejala ini dapat dikaji menurut teori menarik diri (Cumming dan Henry, 1961) yang menyatakan bahwa penuaan adalah suatu penarikan yang tidak terelakan oleh seorang individu dari masyarakat dan masyarakat dari individu yang berakibat pada menurunnya interaksi antara lanjut usia dengan orang lain di dalam sistem sosial yang dia miliki. Proses itu mungkin diawali oleh individu itu atau oleh orang- 
orang lain dalam situasi itu (Esberger dan Hughes, 1989:28).

Berkurangnya hubungan antara keluarga lanjut usia dengan anak, teman, sejawat atau kerabat akan mempengaruhi kondisi psikososial secara keseluruhan. Rasa kesepian karena semua anak telah pergi meninggalkan rumah dan makin sedikitnya teman akrab yang sebaya, umumnya dapat menyebabkan depresi. Perubahan psikososial pada lanjut usia ini menyebabkan munculnya perasaan tidak aman, takut, khawatir akan datangnya berbagai penyakit, sering bingung dan panik (Boedhi-Darmojo, 1999). Hal ini disebabkan oleh ketergantungan fisik dan faktor sosial ekonomi sehingga dapat dikatakan bahwa faktor psikososial ini sangat tergantung pada aspek sosial ekonomi. Sekalipun ada indikasi semakin berkurangnya hubungan sosial keluarga lanjut usia, namun di lokasi penelitian masih banyak keluarga lanjut usia yang tetap mempertahankan bentuk keluarga luas.

\section{Berdasarkan hasil wawancara} dengan beberapa informan dapat diketahui hal-hal berikut ini: Bapak Sabri seorang nelayan lanjut usia yang berumur 61 tahun, yang beralamatkan di Jorong Pasar dua suak. Pendidikan terakhir beliau adalah tidak tamat Sekolah Dasar, yaitu hanya sampai kelas 3 Sekolah Dasar. Beliau memiliki satu orang istri yang bernama Maswati yang berusia 45 tahun dan tujuh orang anak, yang terdiri dari 5 anak perempuan dan 2 orang anak laki-laki. Dimana 5 anak perempuan beliau telah berumah tangga dan yang masih menjadi tanggungan beliau sekarang adalah 2 orang anak laki-laki beliau yang masih bersekolah.

Bapak Sabri merupakan salah satu nelayan lanjut usia di Jorong Pasar Dua Suak ini yang masih melakukan aktifitas melautnya. Menurut beliau ada mayoritas mata pencaharian di jorong tempat tinggal nya adalah nelayan sekitar $90 \%$, pedagang sekitar $5 \%$, petani sekitar $3 \%$, dan pegawai sekitar $2 \%$. Sedangkan nelayan yang lanjut usia sekitar $10 \%$ dari total nelayan yang ada. Jadi bisa dikatakan bahwa nelayan adalah pekerjaan utama di nagari air bangih ini. Di usia beliau yang telah masuk dalam kategori lanjut usia, kegiatan melaut beliau tidak seperti disaat masih muda dulu. Dalam seminggu biasanya pak Sabri hanya mampu pergi kelaut sekitar 3 atau 4 kali saja, itu pun tidak dalam waktu yang lama.. Beliau sanggup dilaut hanya sekitar 5-6 jam saja. Dikarenakan alasan fisik yang sadah tidak sanggup. Dahulu , waktu di usia muda beliau selalu menjadi pemimpin jalannya perahu dan sesekali penebar jaring. Berbeda dengan sekarang, yang hanya duduk saja dan sesekali hanya membantu menjelaskan arah jalan atau dimana sebaiknya berhenti di tempat yang banyak ikannya. Anak laki-laki beliau juga ikut melaut untuk membantu orang tua nya memenuhi kebutuhan hidup.

Dalam kehidupan nelayan, tauke juga sangat membantu perekonomian para nelayan. Menurut pak Sabri, biasanya apabila beliau kekurangan biaya untuk hidup, beliau biasanya meminjam uang kepada tauke. Tauke yang biasa beliau pinjam uang adalah merupakan nelayan pemilik yang biasa beliau gunakan perahu nya. Sehingga terkadang, hasil melaut pak sabri langsung dip tong oleh tauke untuk membayar hutang. Menurut pak sabri., di nagari ini, ada kelompok nelayan. Beliau tidak termasuk dalam anggota kelompok nelayan tersebut, karena menurut beliau kelompok nelayan tersebut hanya untuk nelayan-nelayan pemilik saja tidak untuk nelayan anggota. Ada banyak beberapa nama kelompok nelayan yang ada di nagari ini, tapi bapak sabri tidak mengetahui dengan jelas apa saja namanya. Begitupun dengan koperasi, beliau tidak tahu pasti apakah koperasi yang ada di nagari itu sekarang masih akatif atau tidak, karena Pak Sabri tidak pernah termasuk dalam anggota.

Pak Sabri terkadang mengalami kesulitan dalam memenuhi kebutuhan hidup nya sehari-hari. Oleh karena beliau berharap ada nya bantuan dari pemerintah untuk membantu perekonomian beliau. Apabila mengalami kesulitan keuangan, beliau biasanya meminjam uang kepada tauke. Tauke yang dipinjam kan uang adalah tauke yang juga nelayan pemilik perahu yang beliau biasa tumpangi. Sehingga, untuk 
penjualan ikan, oleh tauke-tauke tersebut dilakukan pemotongan harga sedikit atas peminjaman uang. Diakui oleh bapak Sabri, beliau tidak sering meminjam uang kepada tauke hanya apabila Dalam keadaan terdesak dan sangat membutuhkan uang seperti uang sekolah anak atau kebutuhan rumah tangga. Beliau meminjam apabila sudah tidak ada penghasilan dalam beberapa hari ataupun dari anak juga tidak mendapatkan hasil ikan yang cukup untuk memenuhi kebutuhan. Untung nya tauke-tauke di nagari atau jorong ini masih mau membantu untuk meminjam kan uang nya kepada beliau.

Menurut pak Sabri, pendapatan beliau dibanding dahulu sewaktu masih muda sangat lah jauh berbeda. Dahulu sewaktu masih muda banyak pekerjaan yang bisa beliau kerjakan, seperti melaut setiap hari, dan dalam satu hari bisa mencapai 2 atau 3 kali ke laut untuk mencari ikan. Selain itu, juga dapat bekerja membantu mengangkat ikan ke TPI, atau berkebun (mencangkul,dll). Sekarang karena kondisi umur dan kesehatan yang sudah tidak mendukung, membuat beliau lebih sering istirahat dirumah menjaga kesehatan. Beliau sekarang lebih sering menderita penyakit batuk-batuk, reumatik atau badan yang sering pusing. Apabila sakit, beliau hanya berobat ke mantari ( bidan) atau ke puskesmas langsung.

Kehidupan sosial juga berubah disaat umur beliau sekarang. Kehidupan hubungan social dengan nelayan lain nya, pak Sabri lebih merasa di hormati dan disegani dalam hal apapun. Seperti dalam hal mengambil keputusan dalam menentukan dimana lokasi yang banyak terdapat ikan, atau dimana daerah yang sedikit karang. Selain itu, beliau juga sering mengikuti kegiatan keagamaan di mesjid seperti pengajian atau ceramah agama. Menurut Pak Sabri di daerah ini tingkat keamanannya sangat baik. Jarang sekali terjadi konflik antar masyarakat sekitar sini. Kalau pun ada hanya konflik kecil dan itu pun dapat segera diselesaikan. Bapak sabri bukan lah seorang tokoh masyarakat tapi karena beliau sudah tua jadi suara beliau juga jadi pertimbangan dalam mengambil keputusan di daerah sini.

Pak Sabri juga memaparkan masalah utama yang ada di daerah ini, yaitu yang paling utama adalah masalah kemiskinan, kurangnya bantuan pemerintah kepada masyarakat. Untuk tingkat keamanan di sisni bisa di nilai cukup baik, karena antar warga saling mengenal dan saling merasa satu keluarga sehigga jarang terjadinya kejahatan dan konflik. Hal yang biasa dilakukan pak sabri untuk tetap menjaga keamanan dan kenyaman di nagari/jorong adalah menjaga hubungan yang baik dengan masyarakat, ramah tamah, dan membentuk masyarakat menjadi sebuah kerabat dan merasa saling bersaudara.

Selanjutnya Bapak Zulkarnain adalah seorang nelayan di nagari air bangih pasaman barat. Beliau berumur 80 tahun berstatus duda dengan 3 orang anak, yaitu 2 orang anak perempuan dan 1 laki-laki. Dua orang anak perempuan beliau telah menikah dan sekarang ikut dengan suami nya masing-masing. Sedangkan anak laki-laki beliau, sudah tidak sekolah dan sekarang membantu beliau untuk melaut.

Bapak Zulkarnain adalah seorang nalayan lanjut usia yang juga salah satu tauke di nagari air bangih. Beliau adalah nelayan penangkap udang. Berbagai jenis udang, dari udang yagn bernilai paling mahal hingga udang biasa, selalu beliau peroleh setiap kali melaut. Jenis - jenis udang tersebut adalah udang Sualo dengan penjualan 40.000-60.000/kg, kelong $\quad 75.000-85.000 / \mathrm{kg}$, .udang mutiara/udang buluh/ udang batu $200.000-300.000 / \mathrm{kg}$.

Informan sejak 2 bulan terakhir tidak pernah lagi pergi melaut, karena alasan kesehatan yang tidak mendukung lagi. Beliau sering mengeluh sakit reumatik dan pegal-pegal, selain itu beliau juga menderita gejala struk yang sekarang sedang dalam pengobatan. Beliau biasa berobat ke dokter umum yang ada di rumah sakit dan juga puskesmas untuk penyakit yang biasabiasa saja. Beliau sekarang hanya duduk saja dikedai menunggu hasil tangkapan udang dan menerima uang nya bersih hasil penangkapan udang. Sekarang 
hanya anak laki-laki beliau yang bertugas menggantikan beliau mengurus semua hal-hal, baik dari untuk melaut, mengatur anggota, mengatur pembagian hasil dan pengumpulan udang di TPI hingga pengiriman ke luar kota atau luar negeri.

Kegiatan utama Bapak Zulkarnain setelah tidak melaut lagi, sekarang hanya mengisi waktu hanya untuk istirahat dan lebih mendekatkan diri ke Allah Swt. Beliau lebih sering mengikuti kegiatan keagamaan di mesjid, atau sering melaksanakan shalat berjamaah di mesjid. Selain itu beliau juga tetap memantau bagaimana kegiatan melaut anggota-anggotanya.

\section{B. Kondisi Riil Keluarga Nelayan Lanjut Usia}

$\mathrm{H}$

asil penelitian yang didapatkan dari masyarakat nelayan lajut usia ini mengalami perubahan dari sistem waktu yang mereka gunakan untuk melaut bagi nelayan lansia menurut beberapa orang nelayan buruh umumnya nelayan lansia hanya sanggup melaut pada saat usia lanjut hanya sekitar 6-7 jam sekali melaut dan aktifitas tersebut pada saat sekarang tidaklah rutin dilakukan setiap hari. Hal tersebut dikarenakan oleh faktor fisik yang sudah tidak sepenuhnya mendukung untuk aktifitasnya nelayan lansia tersebut. pada umumnya nelayan lansia biasanya dalam seminggu hanya sanggup untuk pergi melaut sekitar 3 atau 4 kali turun kelaut. Disini jelas Pekerjaan yang dilakoni oleh nelayan saat usia lanjut berbeda dengan nelayan yang masih muda yang memiliki fisik yang jauh berbeda. Namun pada umunya nelayan lansia hanya sebagai penunjuk arah atau anak hoda/pawang tidak ikut dalam kegiatan seperti menurunkan jaring-jaring tangkapan.

Dalam penangkapan ikan pada masyarakat air bangis yang mana pada masa dahulunya juga terdapat suatu kegiatan yang bersifat semacam upacara yang dulunya diyakini sebagai ritual dalam hal melaut atau yang biasanya mereka sebut dengan tulak bala yang artinya semacam doa bersama yang dilakukan oleh masyarakat nelayan yang bertujuan untuk keselamatan dan hasil tangkap yang lebih banyak. Namun seiring dengan perkembangan zaman tradisi tersebut pada masa sekarang tidak lagi menjadi hal yang utama atau bahkan tidak ada lagi yang melakukan kegiatan tulak bala tersebut, tetapi ada beberapa hal yang biasa dijadikan panduan bagi masyarakat nelayan dalam hal aktifitasnya melaut yaitu dengan semacam aturan yang tidak jelas atau semacam aturan yang tidak tersurat seperti larangan melaut ketika hari Jum'at, namun hal tersebut bukanlah jadi kendala utama bagi masyarakat untuk melaut karena setelah jum'at pun masyarakat nelayan kenagarian air bangis kembali melakukan aktifitasnya untuk melaut. Jika dilihat dari beberapa yang menjadi kendala bagi masyrakat disini untuk melaut ternyata hal seperti larangan/pantangan melaut tidak menjadi permasalahan utama menurut salah satu masyarakat nelayan yang kami temui dilokasi penelitian hal-hal tersebut tidaklah menjadi kendala.

$\mathrm{Di}$ nagari Air Bangis bisa dikatakan terdiri dari tiga jenis sebutan nelayan yaitu nelayan tradisional, nelayan pemilik/juragan dan nelayan buruh/anggota.nelayan yaitu nelayan pemilik/ dengan yg biasa disebut juragan dan nelayan buruh/anggota. Nelayan tradisonal disini pada umumnya hanya menggunakan perahu/sampan, pancing dan jarring untuk menangkap namun hasil yang didapatkan oleh nelayan tardisonal tidak begitu banyak hal tersebut dikarenakan oleh peralatan tangkap yang diguanakan adalah secara sederhana dan hasil tangkapan tersebut hanya dijualkan kepada masyarakat sekitar dan sisanya untuk dimakan oleh anggota keluarga lainnya. Sedangkan Nelayan pemilik/juragan ikan yang memiliki modal banyak yang menggunakan jenis kapal yang besar dan alat tangkap yang sudah memliki standar penagkapan yaitu berupa boat, perahu layar, pencalang. Sedangkan untuk jenis-jenis jaring yaitu jaring bilnek atau biasa disebut jarring hanyut, jaring ikan tamali, jaring banam, jaring udang, pukek udang, dll.

Nelayan buruh/anggota disini berperan sebagai nelayan yang ikut dengan nelayan pemilik atau nelayan ini 
menggunakan kapal dari sinelayan pemilik/ yang bisa mereka sebut dengan juragan kapa/juragan kapal dengan cara semacam sistem peminjaman/sewa. Sistem sewa disini maksudnya adalah yang mana nelayan pemilik meminjamkan kapalnya untuk dipakai oleh nelayan buruh untuk dipakai melaut melalui sistem pembayaranya dengan cara pembahagian hasil tangkapan ikan yang didapatkan dilaut. Sistem pembayaran ikan yang di peroleh dari hasil melaut pertama-tama dikeluarkan dulu berapa semua biaya yang digunakan untuk melaut seperti biaya membeli perbekalan untuk berada ditengah laut selama melaut kemudian dari hasil tangkapan itu dibagi 2 yaitu setengah untuk nelayan pemilk kapal dan setengah untuk nelayan buruh. Namun dalam hal pembahagian nelayan buruh ini juga terhitung dengan berapa jumlah nelayan buruh yang ikut dalam kapal besar tersebut, contohnya nelayan buruh yang ikut dalam kegiatan melaut dengan menggunakan kapal besar tersebut 10 orang jadi seluruh hasil tangkapan itu dibagi dua dan yang setengahnya diberikan kepada sipemilik kapal dan setenganya lagi baru dibagi dengan berapa jumlah nelayan(10) buruh atau jika dipersenkan nelayan buruh perorangnya hanya dapat $1 / 4$ dari seluruh hasil tangkapan selama melaut. Biasanya hasil tangkapan ikan yang ada tersebut langsung dijual ke TPI (tempat penjualan ikan) atau ada juga yang menunggu nelayan dipinggir laut untuk membelinya atau yang biasa disebut dengan toke.

Nelayan di nagari ini menurut penelitian yang dilakukan kebanyakan adalah nelayan buruh atau nelayan anggota. Menurut bapak khairun (salah satu nelayan yang diteliti) perbandingannya antara nelayan pemilik/juragan dengan nelayan buruh adalah sekitar 80\%: $20 \%$ untuk nelayan buruh. dengan menggunakan perahunya. Dengan menjadi seorang buruh nelayan jelas hal tersebut tidak menjadikan masyarakat nelayan dilokasi penelitian ini menjadi lebih sejatera hal tersebut dikarenakan hasil tangkapan yang mereka dapatkan dari hasil melaut tidaklah sepenuhnya menjadi bagian dari nelayan buruh karena hasil tangkapan tersebut harus dibagi dengan penilik kapal dan beberapa nelayan buruh yang ikut dalam kegiatan melaut dengan menggunakan kapal besar tersebut.

\section{Pranata Ekonomi: Koperasi Nelayan dan peran Toke'}

$\mathrm{D}$ Nagari Air Bangis terdapat koperasi nelayan yang bernama LEPN3 yang memiliki jenis kegiatan semacam simpan pinjam terhadap masyarakat nelayan dikenagarian ini dan koperasi ini juga memiliki TOSERBA yang dikelola oleh anggota koperasi. Namun dengan adanya koperasi nelayan LPEN3 ini umumnya masyarakat nelayan tidak menggunakan jasa koperasi tersebut dengan alasan proses dari koperasi tersebut seperti dalam hal peminjaman itu memiliki proses yang sangat rumit dan memakan waktu yang lama jika para nelayan buruh membutuhkan peminjaman terhadap koperasi tersebut. Selain dari koperasi LPEN3 disini juga terdapat semacam lembaga masyarakat nelayan yang bernama KTNA yang berperan sebagai pembinaan masyarakat nelayan yang bersifat pemberdayaan bagi masyarakat nelayan itu sendiri. KTNA yang berada dibawah binaan Departeman Kelautan ini yang bertujuan untuk kesejahteraan nelayan.

Dari wawancara yang kami lakukan dengan beberapa informan nelayan dikenagarian air bangis ini mereka mengaku kurang mendapat pembelajaran baik itu dari koperasi atau lembaga yang ada didaerah ini hal tersebut dikarenakan komunikasi nelayan buruh dengan pihak-pihak terkait yang mengelola kopersai maupun lembaga tersebut kurang berjalan dengan semestinya hal tersebut lebih difokuskan kepada nelayan besar/juragan kapal sehingga nelayan buruh hanya dijadikan sebagai pekerja tetap dalam hal melaut jadi tidak sebagai proses pemberdayaan yang bersifat kemasyarakatan, dan jika dilihat dari peran pemerintah untuk kesahteraan masyarakat nelayan tradisionalpun mereka mengaku tidak pernah mendapatkan bantuan yang bersifat dari pemerintah untuk nelayan seperti bantuan alat-alat tangkap untuk 
melaut akan tetapi mereka hanya mendapatkan bantuan berupa raskin/beras untuk masyarakat miskin.

Selain itu, di nagari ini ada terdapat kelembagaan kelompok nelayan, salah satu nya yaitu kelompok nelayan Sukajadi. Menurut informan, kelompok nelayan ini, tidak ada kegiatan yang begitu berarti. Kelompok nelayan hanya digunakan untuk menerima bantuanbantuan dari pemerintah saja. Bantuan pemerintah pun sekarang sudah mulai jarang. Bantuan yang pernah di peroleh adalah perahu boat dari pemerintah untuk masyarakat yang termasuk dalam kelompok nelayan.Untuj koperasi pun tidak ada di nagari ini, sehingga banyak masyarakat yang kekurangan uang biasanya meminjam uang kepada beliau karena beliau merupakan tauke.

\subsubsection{Strategi Nelayan dalam Menghadapi Lanjut Usia dan Hubungannya dengan Ketahanan Sosial \\ K ebanyakan nelayan disini sudah banyak mengalami usia lanjut yang berkisar sekitar 55 tahun keatas} yang masih melakukan aktifitasnya untuk melaut. Dari beberapa informan yang lanjut usia yang wawancarai mereka mengalami batasan kemampuan untuk melaut hal tersebut mungkin dikarenakan oleh faktor usia yang secara fisik memang sudah tidak sama dengan tenaga yang muda. Menurut salah seorang nelayan buruh yang mengatakan kemampuannya tidak sama dengan dulunya lagi yang biasanya dulu dia sangggup untuk melaut seminggu ditengah laut namun untuk saat sekarang dia tidak mampu untuk berada lama-lama ditengah laut hal tersebut dikarenakan oleh kondisi fisik dan kondisi angin laut yang sangat kuat untuk dia hadapi dalam kondisi lansia sekarang ini.

Kondisi laut yang secara kesehatan memang berdampak langsung terhadap fisik dari nelayan yang sehariharinya melakukan aktifitas dilaut. Dari hasil penelitian dilapangan yang ditemui kebanyakan dari nelayan lansia mengeluhkan penyakit dari terkena langsung air laut berupa reumatik, alergi kulit, sering mengalami pusing-pusing dan berkurangnya penglihatan yang dirasakan oleh masyarakat nelayan lansia, namun dalam kesehatan atau dampak dari penyakit yang mereka rasakan ini umunya mereka hanya memeriksa penyakit tersebut pada puskesmas/mantari yang ada dilingkungan kenagarian tersebut.

Dalam hal kesehatan tersebut sebahagian besar masyarakat nelayan lansia ada yang masih kuat untuk melakukan aktifitasnya melaut dan ada juga dari beberapa lansia yang sudah tidak sanggup untuk melakukan kegiatan melaut, mereka mencoba untuk bertahan hidup dengan beberapa jenis pekerjaan yang dilakukan seperti beralih menjadi padagang kecil-kecilan dengan modal yang sangat sederhana yang dikumpulkan sekian lama dengan membuka warung didepan rumahnya atau menjadi pencari kayu bakar dan hasilnya dijual kepasar dengan tujuan untuk memenuhi kebutuhan keluarganya. Bagi nelayan yang masih kuat untuk melaut biasanya mereka hanya mengandalkan hasil tangkapan atau mereka melakukan peminjaman uang kepada juragan kapal dengan pembayaran setelah mereka mendapatkan hasil melaut. Selain kepada juragan kapal ada juga nelayan yang melakukan peminjaman uang kepada si toke yang mana sistem pembayaranya juga sama dengan pembayaran dengan si pemilik kapal yaitu dibayar dengan hasil tangkapan sewaktu pulang melaut. Jika dilihat dari proses kehidupan masyarakat nelayan dapat dikatakan masyarakat nelayan tradisional dan nelayan buruh sangat sulit untuk bisa jadi nelayan yang sejahtera. Hal tersebut dikarenakan mereka harus terikat pada kondisi fisik, alam dan hubungan ketergantungan antara anak buah dan majikan atau yang biasa disebut dengan patron client.

Masyarakat dikenagarian air bangis ini memang menjadikan laut sebagai tempat mencari kehidupan mereka untuk memenuhi kebutuhan anggota keluarganya hal tersebut dapat dilihat dengan lebih dari $75 \%$ masyarakat air bangis memiliki pekerjaaan sebagai nelayan. Kegiatan melaut yang dilakukan oleh masyarakat air bangis ini umumnya dilakukan oleh laki-laki dan bagi beberapa perempuan hanya berperan sebagai ibu rumah tangga. Jadi dapat dikatakan tidak 
adanya keterlibatan kaum perempuan dalam hal melaut yang dilakukan oleh masyarakat air bangis ini.

Menurut dari beberapa orang nelayan buruh/anggota dikenagarian air bangis yang telah diwawancarai pendapatan yang dihasilkan dari kegiatan melaut pada umunya hanya mendapatkan penghasilan sekitar Rp. 50.000 sampai Rp.75.000/harinya. Dan nelayan tradisional yang hanya mengguanakan peralatan seadanya biasanya berpenghasilan sekitar Rp.25.000 sampai Rp.30.000/harinya. Dari hasil tersebut secara kondisi ekonomi yang mereka butuhkan masih dibawah garis standar kehidupan keluarga untuk mencukupi kebutuhan hidup yang mana terdapat berbagai macam pengeluaran untuk kehidupan yang lebih baik. Namun dalam hal penghasilan jelas mengalami perbedaan yang signifikan antara nelayan tardisonal, nelayan buruh/anggota dengan nelayan pemilik kapal, yang mana nelayan pemilik bisa mencapai penghasilanya sekitar Rp.7.000.00 sampai Rp.1.000.000/hari. Namun hal tersebut juga tergantung pada kondisi laut dan kondisi hasil tangkapan yang diperoleh oleh nelayan tersebut.

Strategi keluarga lanjut usia dalam pemenuhan ekonominya adalah dengan pendapatan yang diperoleh, biasaanya berhutang kepada para tauke atau berhutang kepada siapa saja yang mau memberikan beliau pinjaman hutang. Selain dari itu nelayan lanjut usia meminjam perahu milik nelayan lain dan mencari mata pencaharian alternatif seperti mencari kayu bakar untuk dijual lagi kepada masyarakat yang membutuhkan.

Sebagai warga negara yang baik juga tidak bisa lepaskan dari wujud UUD 1945 untuk mewujudkan ketahanan sosial yang dimiliki oleh setiap warga negara. Begitu juga dalam menjaga ketahanan sosial yang dilakukan oleh masyarakat air bangis yaitu mereka melakukan kegiatan yang bersifat menjalin tali silahturahmi yang baik sesama masyarakat dan saling menghormati satu sama lainnya sehingga terciptanya ketentraman sesama masyarakat sekitar, hal tersebut menurut hasil penelitian disini tidak pernah terjadinya konflik sesama masyarakat di kenagarian Air bangis kecamatan Sungai Beremas Kab. Pasaman Barat.

Hasil penelitian menunjukkan bahwa upaya nelayan lanjut usia mewujudkan ketahanan sosial adalah dengan meningkatkan keamanan di nagari ini saling menghargai, toleransi dan bekerjasama, karena masyarakat Nagari Air Bangis sudah merasa aman. Di Nagari Air Bangis jarang didapai terjadi konflik antar nelayan di sini, kalaupun ada itu hanya masalah kecil saja, maslaah yang bisa langsung diselesaikan. Biasanya nelayan lanjut usia untuk tetap menjaga keamanan antar warga hanya selalu menjaga hubungan baik antar warga, saling menolong bagi siapa yang membutuhkan dan saling menghormat satu sama lainnya. Tidak membedakan status ekonomi ataupun status nelayan mereka. Masalah utama di nagari ini adalah tetap masalah ekonomi masyarakat, karena masih banyak masyarakat sini yang berada dalam tingkat kemiskinan.

\subsection{Kesimpulan}

D roses penuaan yang terjadi pada seseorang merupakan hal yang alamiah dalam kehidupan manusia. Proses itu akan berjalan seiring waktu dengan masuknya invidivu ke dalam masa lanjut usia, yang secara umum ditandai dengan menurunnya kemampuan fisik, perubahan mental, berkurangnya interaksi sosial dan terbatasnya kesempatan di bidang ekonomi. Gejala yang dialami pada masa lanjut usia ini secara langsung mempengaruhi kemampuan seseorang dalam upaya pemenuhan kebutuhan hidup. Kondisi ini mengakibatkan orang lanjut usia harus menghadapi berbagai permasalahan yang kompleks, baik sebagai makhluk biologis, ekonomis, sosial maupun budaya.

Pada masyarakat nelayan, pembatasan masa lanjut usia umumnya ditentukan berdasarkan masa usia produktif, dibedakan dengan pekerjaan nelayan yang mencari ikan di laut lepas dan di sepanjang pantai. Batas unis definitif untuk membedakan antarmasa ini menurut sebagian besar masyarakat nelayan adalah usia di atas 45 tahun, 
meskipun dalam kasus tertentu masih ditemukan nelayan lansia yang masih aktif di lautan lepas.

Permasalahan yang dihadapi nelayan lanjut usia pada umumnya adalah berkurangnya kemampuan untuk mendapatkan penghasilan, adanya gangguan fisik akibat menurunnya kondisi kesehatan, hambatan psikologis akibat berubahnya status dan hubungan sosial serta sulitnya mendapatkan modal untuk berusaha. Pada beberapa keluarga nelayan lanjut usia, permasalahan ini bisa dialami secara keseluruhan ataupun sebagian tergantung bagaimana keluarga lanjut usia memandang hal tersebut.

Setiap individu yang memasuki masa lanjut usia harus mampu beradaptasi dengan kehidupan baru, dengan berbagai pilihan strategi yang diterapkan agar kebutuhan hidup dapat terpenuhi. Kemampuan fisik sebagai modal utama nelayan, apabila semakin menurun maka berpengaruh langsung terhadap pendapatan yang diperoleh, padahal pendapatan ini merupakan jaminan utama berlangsungnya kehidupan nelayan pada masa lanjut usia.

Berbagai strategi yang diterapkan nelayan lanjut usia dalam pemenuhan kebutuhan hidup dan penerapannya dalam kehidupan sehari-hari sangat tergantung pada berbagai faktor sosial budaya serta kemungkinan strategi apa yang dapat dikembangkan. Strategi utama yang dilakukan pada masa lanjut usia di wilayah penelitian pada umumnya adalah tetap bekerja sebagai nelayan, namun disesuaikan dengan kemampuan fisik dan modal yang dimiliki. Oleh karena itu, menekuni pekerjaan sebagai nelayan harisn merupakan prioritas utama, dimana jangkauannya hanya di sepanjang garis pantai.

Pilihan strategi nelayan lanjut usia adalah sebagai buruh nelayan. Pekerjaan buruh nelayan antara lain memperbaiki perahu dan jaring, mengangkat ikan ke TPI, menunggu perahu yang sedang tambat serta mempersiapkan kebutuhan awak kapal/perahu sebelum ke laut. Pekerjaan lain yang dilakukan mantan nelayan lanjut usia adalah pedagang, buruh tani dan peternak. Semua pekerjaan tersebut tidak berkaitan dengan kenelayanan, namun masih memiliki pengaruh dalam bidang sosial dan budaya.

Strategi yang diterapkan oleh nelayan lanjut usia tidak selamanya dapat dikatakan berhasil, karena pilihan strategi yang dikembangkan tidak luput dari kemungkinan kegagalan. Untuk mengatasi kegagalan strategi, baik di bidang nelayan maupun di luar nelayan, para lanjut usia mengandalkan fungsi kerabat dalam rangka mengisi hari tua. Selain itu, dalam kasus-kasus individual para lanjut usia berupaya mengantisipasi nilai kebutuhan yang semin tinggi dengan meminimalkan pengeluaran dan menjaga kesehatan secara teratur. 


\section{Daftar Pustaka}

BPS Pasaman Barat, 2008, Kabupaten Pasaman Barat dalam Angka.

Betke. 2002. Tentang Statitistik Ketahanan Sosial : Menuju Operasionalisasi Konsep Baru dalam Bidang Statistik Sosial (makalah diskusi pakar Depsos).

Bungin, Burhan, 2004, Metodologi Penelitian Kualitatif:Aktualisasi Metodologis ke Arah Ragam Varian Kontemporer, Jakarta: PT. RajaGrafindo Persada.

Cohen, Ronald, 1984, Age and Culture as Theory: Agen and Anthropological Theory. London: Cornell University Press

Danim, Sudarwan, 2002, Menjadi Peneliti Kualitatif, Bandung: Pustaka Setia.

Darmojo, Boedhi. 1999. "Keadaan lansia di Kota Lebih Jelek dibanding di Desa". Kompas, edisi 33 Mei 1999.

Http://www.menkokesra.go.id, Lansia Masa Kini dan Sekarang (17 Januari 2009, 11:07).

Http://www.padangekspres.co.id/content/view/23022/106/, Angka Harapan Hidup Tinggi, Penyandang Cacat dan Lansia Diberi Perlindungan (Sabtu, 15 November 2008).

Hikmat, Harry 2002. Ketahanan Sosial : Konsep, Konstruks dan Indikator (makalah diskusi pakar Depsos).

Hikmat, Harry. 2002. Indikator Ketahanan Sosial (makalah diskusi pakar Depsos).

Menko Kesra, 1996, Pelembagaan Lanjut Usia dalam Kehidupan Bangsa, Jakarta: Menko Bidang Kesejahteraan Rakyat.

Muttahari, Murtadho, 1985, Masyarakat dan Sejarah, Bandung: Mizan

Moleong, Lexy, 2001, Metode Penelitian Kualitatif, Bandung: PT.Remaja Rosda Karya.

Nugroho, Wahyudi, 1995, Perawatan Lanjut Usia, Jakarta: IKAPI

Prayitno, 1983, Usia Lanjut dan Aspek Psikososialnya di Indonesia: Manusia Usia Lanjut. Jakarta: Inti Idayu Press.

Rochman, Achwan.2002. "Ketahanan Sosial Komuniti di Indonesia : beberapa Catatan Empiris)". (Makalah ini disajikan dalam Diskusi Pakar: Membangun Konsepsi dan Strategi Ketahanan Sosial di Departemen Sosial tanggal 7 Oktober 2002)

Sayogyo. 1977. Golongan Miskin dan Partisipasinya dalam Pembangunan Desa. Jakarta: Prisma

Smith and Charlotte Seymour, 1986, Macmillan Dictionary of Anthropology, London: Macmillan Press Ltd.

Tangdilintin, Paulus. 1999. "Sekilas Perkembangan kajian Keluarga Perkotaan" Bunga Rampai Sosiologi Keluarga (Ihromo, ed). Jakarta: Yayasan Obor Indonesia.

Tony dan Hardywinoto, 1999, "Ketika Jumlah Lansia Terus Bertambah" Kompas, edisi 15 Agustua 1999. 